Avrupa Bilim ve Teknoloji Dergisi

Sayı 33, S. 331-337, Ocak 2022

(C) Telif hakkı EJOSAT'a aittir

Derleme Makalesi
European Journal of Science and Technology

No. 33, pp. 331-337, January 2022

Copyright C 2022 EJOSAT

Review Article

\title{
Space Explorations and Asteroid Mining
}

\author{
Levent Özmen ${ }^{1 *}$ \\ 1* MEF Üni GSSS. International Security and Strategic Studies İstanbul, Türkiye, (ORCID:7180 3861), ozmenl@mef.edu.tr
}

(First received 23 September 2021 and in final form 31 January 2022)

(DOI: $10.31590 /$ ejosat.999536)

ATIF/REFERENCE: Özmen, L. (2022). Space Explorations and Asteroid Mining, European Journal of Science and Technology, (33), 331-337.

\begin{abstract}
Space mining is the definition of complex activity work that involves searching for and extracting minerals, elements and water from asteroids and minor planets cruising very close to planet Earth.

In particular, the tendency of commercializing and financing some products used in space technology, which began in the 1980s, led to the start of extensive development projects in America, Japan and Europe. For this reason, space technology has turned into a way in which we work together, directly or indirectly, with its structure that also influenced our lives, its financial structure financed by the whole world, and the scientific cycle of technologies obtained from the working area.

Every work done for life in space, settlement, movement, mining, every development will create a serious change in our life on earth.
\end{abstract}

Keywords: Asteroid Mining, Space, Unclos, NEA, Psyche, ISS, Moon, Rare Earth Elements.

\section{Uzay Keşifleri ve Asteroid Madenciliği}

Öz

Uzay madenciliği, yerküreye yakın konumda seyreden asteroid ve küçük gezegenlerden maden, element ve su arama faaliyetini içeren komplike faaliyet ve çalışmaları tanımlamaktadır.

Özellikle, 1980'lerde başlayan, uzay teknolojisinde kullanılan bazı ürünlerin ticarileştirilerek finanse edilmesi politikası, Amerika, Japonya ve Avrupa'da geniş kapsamlı geliştirme projelerinin başlamasını sağlamıştır. Bu sebeple uzay teknolojisi günlük yaşamımıza etki eden yapısıyla, tüm dünyanın finanse ettiği mali yapısı ve çalışma alanından elde edilen teknolojilerin hayatımıza yer alan bilimsel döngüsüyle direk veya dolaylı olarak hep birlikte çaba sarf ettiğimiz bir yola dönüşmüştür.

Uzayda yaşam, yerleşim, hareket, madencilik için yapılan her çalışma, elde edilen her gelişme dünyadaki yaşamımızda ciddi değişiklik oluşturacaktır.

Anahtar Kelimeler: Asteroid Madenciliği, Uzay, NEA, Psyche, Ay, Nadir Toprak Elementleri. 


\section{Introduction}

The asteroids which approach and glance off Earth, then reach its surface as small pieces have become regarded as great value for the future of the world.

Discovery of the asteroids and the Titius-Bode law which foresees that the planets are aligned according to a mathematical sequence, were generated by J. D. Titius as a formula in 1766 and by J. D. Bode in 1778 as they generated a logic which expresses the idea that the planets are not located in a coincidental manner in space. "Ceres" which was first thought to be a planet was discovered by Giuseppe Piazzi in 1801 at the distance foreseen by this formula. Today, it's stillused for the discovery of other celestial bodies on similar orbits.

Even though the formula was not in use during the discovery of Uranus, it was utilized for the discovery of many small celestial bodies between the orbits of Jupiter and Mars; later on, discoveries continued as the formula included the celestial bodies that are located inner in Mars and outer in Jupiter's orbit. [1]

Some of the reserves of metals and minerals that are necessary for developing technological products are not enough for widely usage, or the metals and minerals require rather difficult processes for obtaining even small amounts. Some of the important resources of the earth are about to diminish soon due to known terrestrial resources and increased consumption. New and inspiring discoveries and high amounts of some of the elements in periodic table are needed for increased popularity and utility of already used technology; and making future discoveries with more complicated system technologies for industrial and technological development of humanity.

Asteroid mining that science fiction authors, space scientists and engineers hypothesize about possible advantages remained as a distant dream due to technical, financial and political difficulties. As the series of missions conducted on asteroids came together with the earth based observations and works, all of these gave rise to realization of that the asteroids contained high amounts of valuable resources. [2]

Appropriate experimental works and multidisciplinary approaches have turned this to one of the widely researched area ones. The term "Space Mining" started to develop as a matter of fact that could be carried out in medium term in the beginning of 90's. After the 'SPACE' Act that was approved by US congress in 2015 and the Act for establishing a space force was approved in $20^{\text {th }}$ of December 2019, space mining officially became a subject of near future. [3].

\section{Material and Method}

\subsection{Planning on Conducting the Asteroid Mining}

Space mining includes the investigation of the data collected from the researches on Mars and Moon for the opportunities of permanent presence, habitat, travel and asteroid mining. Asteroid mining defines the research of those high-tech products that are meant to be applied on moon and asteroids which are in close proximity of the Earth, as well as the management of activities on or outside the asteroids pursuant to reaching targeted celestial bodies with spacecrafts carrying drilling machines. The purpose is to make use of the rare metals and the water that has tremendous amount of importance for deep space explorations, with those materials drilled for on the earth or in space. Currently there is no company that is capable of conducting all these actions. However, leading US companies "Deep Space Industries", "Planetary Resources", "Moon Express" and "SpaceX", alongside a Japanese company "Ispace" are conducting tests and R\&D activities for different stages of such operations in order to achieve competence. [4]

The primary goal of these companies is to conduct mining to the extent possible and carry out research on more than six thousand asteroids passing near by the Earth's orbit in the timeframe of 2030-2065, with maximum 6 years period spent per mission. [5]

Greatest difficulty of this type of mining entrepreneurship lies on the estimation of economic feasibility such as predicted costs related to asuch major scale operation and prediction of the market value of any obtained material, after the effect they generate on the market. The main costs and their effects are being calculated in order to shape technological developments. Predictions of this kind aim to estimate by relating the costs with physical, technical and expected performance parameters through mathematical correlations. Result of these predictions shapes the tendency of the R\&D projects as well as resource and time spent on the targeted projects. [6]

Currently the cost of lifting off a mass of 1 kilogram to the level of low earth orbit is 60000 USD. Operations involving tons of masses are dangerous and contain high risks. The cost of fuel, which is 1 dollar in the world, is about 2-3 thousand dollars according to current estimates. [5] , [7]

It would be more appropriate to understand the goals of space mining by examining the occurrence of the historical process that carried everything to this point and to this purpose.

\subsection{Historical Background}

It is known that Chinese made the first missiles and the works that required black powder to provide thrust force have a history of 2000 years. [8]

It is also known that Chinese used "flying burning arrows" made out of saltpeter, sulphur and wood coal powder against Mongols during Kai-Keng war in 1232; and Mongols took over Budapest by using the same technique against Magyar forces during Sejo war in 1241 after learning the technique in a short time.

In 1633 Lagari Hasan Çelebi has achieved to take off with the first human carrying rocket in İstanbul, Sarayburnu.

English artillery specialist colonel William Congreve would transform the rockets that Indians used in wars against them in years between 1792 and 1799 to the ones that British and Americans used in year 1812 .

One of the most important progresses in this area started when a Russian teacher Konstantin Tsiolkovsky (1857-1935) proposed the idea of space exploration with rockets using liquid fuels together with basic calculations. With the works done for this purpose, American Robert H. Goddard succeeded to make a rocket that used liquid fuel, which could escalate 12 meters and travel for 55 meters in 3 minutes in the year 1926. [9] , [10]

Effective narrative of the novel "Die Rakete $\mathrm{zu}$ den Planetenräumen”, written by physicist Hermann Oberth in 1923, 
would gave rise to the beginning of many historical events. Adventure started by the members of 'Verein fur Raumschiffahrt' society who were touched by the ideas in Oberth's novel and their collaboration gave rise to the gathering of the crew that started the modern-day technology. In 1937, German engineers and scientists including Oberth gathered in Peenemunde in Baltic seashore. Since therefore, production of the first V2 rockets that could go up to space and become the most effective weapon of WWII, got started. This crew was going to be the basic actors in exploration of space. US and Russian forces that broke into Berlin in WWII looked for production site and plans of these effective weapons as well as Werhner von Braun and his team who developed all of this. A US team was the first to reach the production line of V2s near a concentration camp. The project team who created V2 rockets would later divide and go to US and Russia after end of the WWII. [11], [12]

Russian space program, being conducted under the leadership of Sergey Korolyov a scientist whowas exiled in 1938. The satellites launched by Soviet Union Sputnik I and Sputnik II that carried living animals to the space were the first successful launches that started the space race between two superpower countries.

From the moment the Sputnik satellite was successfullylaunched and orbited the Earth, the United States was considered by the whole world that it was vulnerable to a Russian attack. By sending Yuri Gagarin into space in 1961, the Russians broke new ground in human history.

The US launched the Explorer I satellite into space in January 1958, a few months after the first Sputnik. In 1969, the first manned space flight to the Moon with the Saturn V Rocket designed by Werhern von Braun, with the Apollo 11 mission, crossed a huge limit in the space race.

The Mir Space Station, which the Soviet Union sent into space in 1986, is referred as the first space station in real terms. It remained in orbit for 15 years and contained cosmonauts for 10 years. The International Space Station (ISS), made of multiple habitable space modules, has been orbited at approximately $400 \mathrm{~km}$ from Earthsince November 2000, is a joint project of NASA (USA), Roscosmos (Russia), JAXA (Japan), ESA (Europe) and CSA (Canada). Ownership and use of the space station are determined by intergovernmental agreements and contracts.

China, which did not participate in the program while the ISS was in orbit, continued its own space station program. China launched the Lunar Exploration Program in 2004, named after CHANG, the 'Moon Goddess' in Chinese mythology. A new era has started when the Chang 5 spacecraft, conducted by geologist Quyang Ziyuan and designed by $\mathrm{Hu} \mathrm{Hao}$, landed on the dark surface of the Moon in 2020 and took a sample. When the spacecraft's capsule full of rocks and earth returned to Earth from the Moon, it set the stage for a new space race over the use of space resources in the coming decades. With these developments, it seems clear that there will be competition over the evaluation of resources on the moon that could advance deeper space exploration. [13] - [21].

\subsection{Technical Background}

The countries that are leaders in steel production and energy consumption have shown that they are the primary power in the world. [22]

Prior to the First Industrial Revolution, the Ottoman Empire was in the first place in steel production, and with its historical superiority, she was also in the first place in human labor force and energy production. With the industrial revolution, the British started to produced large amounts of steel with their mass steel production process and turned coal energy into labor force with steam locomotives, which far surpassed all countries based on the human labor force. With the industrial revolution, England became the leader in the world as a result of obtaining the labor and energy obtained by using slaves with machines and coal. Before the Second World War, Germany stepped in and took the leadership, yet the USA and Russia who won the victory against Germany in the WWII, became the top two countries of the World, in steel and energy production. In an effort to be in the race,p, the European Coal and Steel Community was established, which would ultimately become the European Union. As a result of the fact that China produces as much as the total steel production in the world, it has taken the leadership by far today. [23] , [24], [25]

While economic and military struggles continue to have energy and iron ore mines in various parts of the world, research continues in many $R \& D$ centers for new materials and in many centers including CERN for energy production methods. The space domain also offers a totally new endless fields of research for minerals and energy research.

In addition to obtaining steel and energy production raw materials in order to seize power, asteroid mining will provide a scientific and technical way to have the power to gain a vital dimension that will push all current limits with the technology to be developed.

So what is this mining and what does it aim at?

\subsection{Asteroid Types}

We live on earth in the solar system located in the Milky Way galaxy, which is a small part of the universe. In this sense, possible resources from space are expected to be similar to the elements already present in our world. Possible resources from space have been a subject of research with the idea that they could be building blocks for interplanetary exploration and a solution to the limited supply of important natural resources that are accessible on Earth.

Objects orbiting the Sun in general are;

1- ) Planets and moons.

2-) Comets, which are meteorites composed of pieces of water, ice and frozen gases and dust.

3-) Dwarf planets. (Large diameter asteroids, usually in the region between Mars and Jupiter)

4-) Asteroids with celestial bodies between Mars and Jupiter.

5-) They are grouped as trans-Neptune objects(TNO). [26]

The term asteroid is used for objects larger than meteorites, smaller than planets, and following slightly elliptical, stable 
orbits in the Solar System, which consist of rock formations rather than ice.

Asteroids have been identified as the most interesting structures in terms of research among structures orbiting the Sun, due to their small masses compared to planets, their origin from outside the solar system, their structural diversity and their intense metallic minerals.

It is thought that there are around 60 million asteroids in our solar system, and about 600 thousand of them have been identified by human beings. We divide these studies into two groups. The first is the asteroid belt that orbits our earth, occasionally passing in close orbits. These asteroids, whose short names are called "NEA: Near Earth Objects" and their number is around twenty thousand, are prime candidates for mining operations. The second and largest is the main asteroid belt, which is located between Mars and Jupiter and is growing each year. The most known of this group, which is likely to contain richer metals and minerals, is the asteroid named "Psyche".

NEAs are studied in three groups: Asteroids that pass through the orbit of Mars, asteroids that orbit the Earth for more than a year, and asteroids that orbit the Earth for less than a year. [27] , [28]

Getting information about asteroids is done predominantly in three ways. The first is the studies on small meteorites which are often called "shooting stars" that fall on our world. The second is the analysis made by sending various signals using the remote sensing method with geophysical procedures, and the third is in the form of receiving information through spacecraft landing studies that closely examine the asteroid. Today, the work of sampling from asteroids has been proven by the successful flight missions of Hayabusa and Stardust projects.

In the light of research conducted in this field, , asteroids are grouped into 3 types. [29] , [30] , [31]

\subsubsection{Types $C$ (namely carbonaceous asteroids):}

Type C, mostly at the extreme outer edge of the asteroid belt and asteroids are estimated to be more than 75 percent of the total. Platinum group metals are only found in this asteroid group. They contain clay silicate and $\mathrm{H} 2 \mathrm{O}$, as well as high levels of phosphorus and organic carbon needed to produce fertilizers which may be needed for growing crops. The composition is thought to be similar to the Sun, hydrogen, helium and other volatiles. Type $\mathrm{C}$ asteroids inhabit the outer regions of the main belt. Albedo values It ranges from 0.03 to 0.09 . The surface of such asteroids is almost as black as coal. (The capacity to reflect electromagnetic energy falling on a surface, that is, the reflective power of the surface, is called 'albedo'. Albedo refers to the measure of an object's reflectivity or intrinsic brightness. A white, perfectly reflective surface has an albedo of 1.0; The black, excellent absorbent surface has an albedo value of 0.0.) [32].

Type $\mathrm{C}$ asteroids are full of volatiles, which, though not especially valuable on earth, would be incredibly valuable to space ventures by providing them with water, hydrogen, and oxygen. [33]

\subsubsection{Types $S$ (Siliceous asteroids):}

These are estimated to be 17 percent. Metallic iron mixed with iron, magnesium, nickel silicates are found on their mass and Platinum, Gold, Cobalt, Radyum, Titanyum, Molibden are also found in these types of asteroids. This group will help offset the rising cost of asteroid mining. Their composition possess metallic iron and magnesium silicates mixed with iron. S-type asteroids dominate the interior asteroid belt. Albedo values range from 0.1 to 0.22 . [32]

\subsubsection{Types M (Metallic asteroids):}

The rest belongs to this group. M-type asteroids are situated in the middle zone of the main belt. They are moderately bright. Albedo values range from 0.1 to 0.18 . Types $M$ is represented in meteorite collections on Earth.

Originally discovered in 1852, 16 Psyche is the largest Mtype asteroid. They contain metallic nickel and iron. They can contain up to 10 times the amount of precious metal ore found in an S-type asteroid. Sufficient analysis results have not been obtained yet for more information, yet it seems that the composition is dominated by metallic iron. The missions Hayabusa and Stardust have returned material samples to Earth on type $m$ asteroids. [32]

\subsection{What are Space Mining Goals?}

\section{What do we aim for Studies in Space?}

We do our research on asteroids for three main purposes.

The first is to establish a colony in the world and space in the future with what will be obtained from water and valuable mining activities. The second is to place a spacecraft on the asteroid that has an orbit outside our solar system, so that research can be made into the depths of space and black holes, while moving with an asteroid orbit. Used to prevent possible hazards. Asteroids that pass close to our world pose a risk of impact, which pose a great risk to humankind. Studies are carried out to calculate the risks and take precautions. [34]

Availability of raw materials in space eliminate the cost of bringing materials into orbit, thus greatly reduce the overall cost of construction. Such facilities would provide the ability to build and move in space, much larger spacecrafts than those can be built on Earth.

While the technological advances in our world demand some elements more than those found in the world, it is estimated that ores such as iron, nickel and manganese, which we use in large quantities in industry, will soon become insufficient to meet our needs.

From such point of view of changing our direction to space, it seems extremely costly and difficult to transport fuel, water and building materials from Earth to space. There is a need to build a center to conduct research in space, to move from , and to establish a colony in the future for logistics and production. For this, there is a space station that has been studied for a long time. While examining the morphology and chemistry of the regolith on the lunar and Martian surface from many aspects, how it can be evaluated as a building block is also examined. 3D printers are being developed to enable the production of these materials. 
In the field of space exploration, although solar wind and geothermal sources are studied primarily as possible sources of energy, research on the helium 3 source also continues.

As an alternate source of energy, solar radiation is also an important driver of space weathering on airless bodies.

Over time, exposure to solar radiation changes the physical, chemical, and optical properties of exposed materials and can also deliver significant amounts of helium to the surfaces of these objects. This is one of the important research topics of space mining as a powerful energy resource.

The 'sine qua non' of the strategy of space mining and exploration is for water resources. Hydrogen and oxygen are critically important as the two most essential materials in space.

Water is the most critical component in the human life cycle, agricultural production, and fuel for spacecraft and equipment. It is possible to separate water into hydrogen and oxygen by taking solar energy for 24 hours in space, without the effect of the atmosphere, and to recombine them through fuel cells to obtain electricity. Technologies that support the water economy will play an important role in leading space development.

It is extremely costly to bring water from Earth to space. When defying gravity with machines, every gram of rocket fuel on board can count in the overall cost.

Rare Earth Elements and Platinum Group Metals, which are depleted in earth resources, are much needed in our world for the development of our technologies. Along with gold, iron, nickel, cobalt, silica, ruthenium, neodymium and similar elements, lanthanide group elements are also indispensable for developing new technologies. Nickel and iron content, which is almost in pure form in asteroids, is also an ideal raw material source for the ongoing steel industry and steel production in our world. [35] , [36] , [37]

We also aim to learn new information that will exceed the limits of obscurity, such as a new unknown element in the periodic table or new biodiversity that will show the properties of life in space, or more detailed information from black holes.

The use of the Moon and the space as a defense base for any natural or extra-terrestial attack on the Earth is also included in these activities. [36] -[41]

\section{Results and Discussion}

We are at the very beginning of such a big operation. Our technical and operational capabilities put on one side, everything else from economical and social perspective is only in an unpredictable state of uncertainty.

\subsection{Administrative Problems}

Debates continue as to whether companies, countries, or the entire world doing research in the space domain have any value. Discussions in this field are carried out to bring resolution through the concepts of outer space, orbital space and deep space, from the perspective of international maritime law, through the "United Nations Convention on the Law of the Sea".

While companies want to be rewarded for their hard work in this area, the states that support and lead this demand regard their rights in this area. On the other hand, of any disease, attack e-ISSN: 2148-2683 or asteroid presence coming from outer space will affect all people on earth and that they should be accepted as the common heritage of humanity, gains weight. This view maintains that all human beings have the right to contribute to the attainment of this level of knowledge and work done to bring humanity into space.

Air law began with the ratification of the full and exclusive sovereignty of a state over the upper airspace in the 1919 Paris Convention. Space law began to be discussed with the launch of Sputnik I in 1957 and Explorer in 1958.

'Agreement for the Rescue of Astronauts, Return of Astronauts and Return of Objects Launched into Space' in December 1968, (Registration Convention) was adopted by the United Nations General Assembly in 1976 and entered into force. Although the Governing Principles describing the Activities of States for the Use and Exploration of Outer Space, including the 'Moon and Other Celestial Bodies', which have been negotiated since 1967 and called the 'Outer Space Treaty', have been previously declared, the governing principles that determine the activities of states on the Moon and their rights in other celestial bodies (Moon The Agreement entered into force in 1984 at the United Nations General Assembly. According to this agreement, the exploration and use of outer space should be done for the benefit of all countries and will be under the common authority of all humanity.

In addition to these agreements, which are called 'Five Treaties', which have an important place in the field of space law, various declarations were also accepted in the United Nations General Assembly. [42] [43]

Although the principle of 'the peaceful use of outer space' in space law is widely accepted as 'jus cogens', it is clear that the states and the private companies they support, are on the scene of a 'domination war' in space. [42], [45]

While all humanity will be affected by diseases or attacks coming from space, it is argued that what kind of way to counter these attacks and that all humanity should share the benefits from space due to these risks. There is also uncertainty about how and to whom the precious metals and minerals to be obtained from space will be taxed when processed on earth or in space. Since the winner of the space race will be the center of gravity in the balance of power in the world, it is clear that the winner of this race will impose her own law. Questions of how the rights of humanity will be protected and how the countries carrying out research activities will finance these researches, will also affect the decisions yet to be made in future.

While all this is happening, there is no consensus on how and in what way the power center will be structured to ensure the protection of rights in space law.

\subsection{Operational Problems}

The operation of capturing, transporting, and processing raw materials from asteroids situated in space is only a paper-based mission architecture. The operation of making it ready for production by bringing it to the desired shape and level in the World, is also just a thought on paper.

Unfortunately, no mining techniques have been developed specifically for the zero/microgravity environment, yet. 
The problem of mineral dust on the lunar surface, similar to a kind of silica dust, with production devices such as spacecrafts and 3D printers, is obvious problems in terms of human health.

Scientific studies are continuing on making robots with renewable organic or inorganic structure for production in space and the first settlement in space.

Studies on eliminating the biological and radiation risks of these structures have not yet been defined. The effects of such a high and precious metal production in terms of the world economy and the new market conditions are also uncertain predictions.

In addition, according to the data of the European Space Agency, waste, consisting of more than one hundred million pieces and approaching ten thousand tons, is circulating out of control in orbit at speeds approaching 30 thousand $\mathrm{km}$ per hour. [46]

\section{Conclusions and Recommendations}

Space mining has its historical origins in ancient blacksmiths who forged swords from meteorites.

We witness that the structures designed as dreams turn into steps in order to realize our dreams as our technical power progresses.

Robust technical and economic approaches to project planning and feasibility assessment are needed to evaluate space mining initiatives.

The development of asteroid mining will require the development of many technologies. On the other hand,

asteroid mining technologies improvements, could lead to more research and applications for know elements in the future.

From mineral extraction to processing to zero-gravity production, these technologies will fuel the leapfrog expansion of humanity across the Solar System, just as direct mining and agricultural opportunities have spurred human expansion worldwide.

The great technological advances provided to those countries by the technical progress their leadership in steel and energy ensured world domination and the efforts to went into space, are in the memory of our recent history. It is clear that the advances to be made in the field of space mining will technically and socially open a new era for our world and humanity.

From today's world, where the leading country in technology exerts its power over the world by controlling the production of knowledge, we will step into a world where the countries that will be successful in space technologies will also process the cultural codes and laws. New discoveries created for power will bring new legal systems and laws to be re-written and a whole new world where the truth of those who will write them will be added.

As human beings approach the limit of their dreams, they will also test the power they want to achieve in order to realize their wishes, with human values.

Our contact with space, travel and lifestyles will bring a new measure of time and lifestyle, with an inevitable transformation.

\section{References}

[1] Aksoy Y. Bilim-Felsefe-Tıp ve Teknoloji Tarihinden Seçilmiş Konular. Yüksek Lisans Tezi, Yıldız Teknik Üniversitesi, İstanbul Türkiye 2013

[2] Vergaaij M, Mcinnes CR, Ceriotti M. Economic Assessment of High-Thrust and Solar-Sail Propulsion for Near-Earth Asteroid Mining. Advances in Space Research, S02731177(20)30414-2 , 2020

[3] U.S. Dept Of Defense. Trump Signs Law Establishing U.S. Space Force. https://www.defense.gov/Explore/News/Article/Article/2046 035/trump-signs-law-establishing-us-space-force/ (Accessed: 23.01.2021)

[4] Asteroid Mining May Be a Reality by 2025. Mike Wall. https://www.space.com/30213-asteroid-mining-planetaryresources-2025.html (Accessed:08.03.2021)

[5] Colvin TJ., Crane K., Lal B. Assessing the economics of asteroid-derived water for propellant, Acta Astronautica, S0094-5765(20)30312-X. 2020

[6] Probst A., Nitzl C., Kraus F., Förstner R. Cost Estimation of an Asteroid Mining Mission using Partial Least Squares Structural Equation Modelling (PLS-SEM). Journal Preproof, AA7623, p.440-454, 2019

[7] M. J. Sonter, "The Technical and Economic Feasibility of Mining the Near-Earth Asteroids," Acta Astronaut., is sepivivol. 41, pp. 637-647, USA 1997. SLỆ.

[8] Pellandini J. Les Fusees, B00B5A7L6A Presses Universitaires de France, s. 5.,Paris 1958

[9] The Time. He launched the space age with a 10-ft. rocket in a New England cabbage field. https://web.archive.org/web/20090524195212/http://www.ti me.com/time/time100/scientist/profile/goddard.html (Accessed: 20.03.2021)

[10] Uni.of Michigan, The past and Future of Rocket Engine Propulsion,

https://web.archive.org/web/20120730011727/http://fathom. com/course/21701743/session1.html (Accessed: 08.09.2021)

[11] History İnformation. The Initial Interrogations of the Nazi Rocket Team and the First Publication Outside of Nazi Germany of Rocketry Research at Peenemunde East. https://www.historyofinformation.com/detail.php?entryid=3 989 (Accessed: 12.03.2021)

[12] Goinor C. The Rocket Pioneers., Universty of Nebraska Press, p.11-48., USA 2013

[13] NASA. Apollo 11 Mission Overwiev., https://www.nasa.gov/mission_pages/apollo/missions/apollo 11.html (Accessed: 15.09.2020)

[14] NASA. Brief History Of Rocket. https://www.grc.nasa.gov/www/k12/TRC/Rockets/history of rockets.html (Accessed: 29.10.2021)

[15] Uni.of Michigan. The Creation of the Modern Rocket. https://web.archive.org/web/20120730011700/http://fathom. com/course/21701743/session2.html (Accessed: 23.04.2020)

[16] STM.Yeni Uzay Çağ1. https://thinktech.stm.com.tr/uploads/raporlar/pdf/311220201 03922510_stm_yeni_uzay_cagi_4.pdf_Accessed: 20.20.2020)

[17] The New York Times. China Brings Moon Rocks to Earth, and a New Era of Competition to Space. https://www.nytimes.com/2020/12/16/science/china-moonmission-rocks.html (Accessed: 12.03.2021) 
[18] The State Council of China. The State Council Information Office held a press conference on the mission of the lunar exploration project Chang'e

5. http://www.gov.cn/xinwen/202012/17/content 5570431.htm (Accessed: 01.05.2021)

[19]

$$
\text { NASA. Sergei }
$$

P.Korolev. https://history.nasa.gov/sputnik/korolev.html 19.06.2021)

[20] NASA.Werhern

Von

(Accessed:

https://www.nasa.gov/centers/marshall/history/vonbraun/bio html (Accessed: 19.12.2020)

[21] NASA.History Series Publication. https://history.nasa.gov/series95.html

(Accessed: 22.01.2021)

[22] Visual Capitalist. Visualizing 50 Years of Global Steel Production. https://www.visualcapitalist.com/visualizing-50years-of-global-steel-production/ (Accessed: 04.04.2021)

[23] World Steel Assoc. Global crude steel output decreases by $0.9 \%$ in 2020 . https://www.worldsteel.org/mediacentre/press-releases/2021/Global-crude-steel-outputdecreases-by-0.9--in-2020.html (Accessed: 04.04.2021)

[24] UK Parliament. Steel Industry.

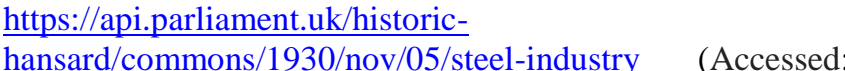
19.05.2021)

[25] Europain Union. The History of the Europain Union. https://europa.eu/european-union/about-eu/history_en (Accessed: 03.04.2021)

[26] NASA. Asteroid Watch. https://www.jpl.nasa.gov/asteroidwatch (Accessed: 08.03.2021)

[27] NASA. What is Planetary Defense? https://www.nasa.gov/planetarydefense/faq (Accessed: 30.08.2021)

[28] Clas G. Wihlborg CG., Magnus Wijkman P., Outer Space Resources in Efficient and Equitable Use: New Frontiers for Old Principles. The Journal of Law \& Economics, 24(1):2343, The Uni. Of Chicago Press 1981

[29] Calla P., Fries D., Welch C. Asteroid mining with small spacecraft and its economic feasibility. Cornell Uni, 2019

[30]

NASA.

Hayabusa.

https://www.jpl.nasa.gov/missions/hayabusa

(Accessed:18.09.2021)

[31] NASA. Stardust. https://www.jpl.nasa.gov/missions/stardust (Accessed 21.12.2020)

[32]

NASA.

Asteroids. https://nssdc.gsfc.nasa.gov/planetary/text/asteroids.txt (Accessed:21.03.2021)

[33] Crerend A., Asteroid Mining, Stanford Uni.,USA 2014 http://large.stanford.edu/courses/2014/ph240/crerend1/ (Accessed : 09.01.2022)

[34] NASA. NEO Earth Close Approaches https://cneos.jpl.nasa.gov/ca/ (Accessed:09.09.2021)

[35] Metzger PT. Space development and space science together, an historic opportunity. Space Policy, Volume 37, part 2, p.77-91,August 2016,

[36] Tao Zhang vd..Review on Space Energy.Applied Energy Volume 29, 15 June 2021, 116896

[37] K.D.Burgess \& R.M.Stroud. Phase-dependent space weathering effects and spectroscopic identification of retained helium in a lunar soil grain. Geochimica et Cosmochimica Acta,Volume 22, Pages 64-79, March 2018

[38] Sanchez J., McInnes C., Asteroid Resource Map for NearEarth Space. Journal of Spacecraft and Rockets 48 (1), p.153-165, 2011

[39] Alotaibi G., Boileau J., Bradshaw H., Criger B., Chalex R., Chun J., Desjardins D., Dhar J., Artiles A., Ellis K., ASTRA: SEP Asteroid mining technologies roadmap and applications, p.1-100, International Space University 2010.

[40] J. P. Sanchez, C. R. McInnes, Assessment on the feasibility of future shepherding of asteroid resources, Acta

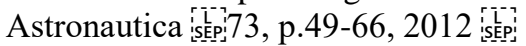

[41] Interesting Engineering. Mining in Space. https://interestingengineering.com/mining-in-space-what-itmeans-for-the-economy (Accessed: 12.03.2021)

[42] United Nations Office for Outer Space Affairs. Documents and Resolutions Database.

https://www.unoosa.org/oosa/documents-andresolutions/search.jspx?\&view=resolutions (Accessed: 10.06.2021)

[43] Sarıkaya S., Uzay Hukuku ve Türkiye, Nobel Bilim Yayınları, İstanbul 2020, p.20-29

[44] Yevgeniya O., Jus Cogens Norms in International Space Law. Mediterranean Journal of Social Sciences, Vol 6 No 6 ISSN 2039-9340, MCSER Publishing, Rome-Italy November 2015

[45] Europan Parliament. Space Mining. https://www.europarl.europa.eu/doceo/document/E-8-2016005146_EN.html (Accessed: 21.03.2021)

[46] The European Space Agency. Space Debris By the Numbers.

https://www.esa.int/\%20Safety_Security/Space_Debris/Spac e debris by the numbers (Accessed: 17.05.2021) 